FORMATION Formation emploi

Revue française de sciences sociales

107 | juillet-septembre 2009

La formation professionnelle en Amérique latine

\title{
Des (bonnes) pratiques situées
}

Jean-Frédéric Vergnies

\section{(2) OpenEdition \\ Journals}

Édition électronique

URL : http://journals.openedition.org/formationemploi/1969

DOI : 10.4000/formationemploi.1969

ISSN : 2107-0946

Éditeur

La Documentation française

Édition imprimée

Date de publication : 1 septembre 2009

Pagination : 1

ISSN : 0759-6340

\section{Référence électronique}

Jean-Frédéric Vergnies, « Des (bonnes) pratiques situées », Formation emploi [En ligne], 107 | juillet-

septembre 2009, mis en ligne le 19 novembre 2009, consulté le 30 octobre 2020. URL : http://

journals.openedition.org/formationemploi/1969; DOI : https://doi.org/10.4000/formationemploi.1969

() Tous droits réservés 


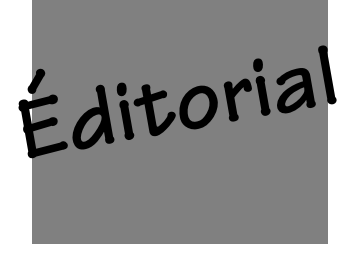

\section{Des (bonnes) pratiques situées}

e dossier de Formation Emploi invite à la découverte de quelques réalités de l'enseignement technique et de la formation professionnelle en Amérique latine. Il apparaît que les systèmes de formation sud-américains ont été influencés par les systèmes européens. On retrouve ainsi des questions familières aux lecteurs français : les rapports difficiles entre enseignement général et enseignement technique ou professionnel, ou entre formation initiale et continue ; la rémanence de l'adéquationisme et de l'introuvable relation formation-emploi ; la participation inégale des partenaires sociaux ; le rôle des familles et de leurs représentations ; les différenciations et les discriminations entre femmes et hommes...

Ainsi, Martin Spinosa et Julio Testa analysent les relations entre le travail et la formation professionnelle en Argentine selon une perspective historique. Maria de Ibarrola souligne l'impact de l’hétérogénéité du marché du travail sur la formation professionnelle au Mexique. Claudia Jacinto analyse comment le programme « Pro-jeunes » (projoven) en Uruguay, dispositif de formation et d'insertion des jeunes peu qualifiés, a pu perdurer dans un contexte changeant. Enfin, Mariela Quiñones Montoro interroge le passage à la logique compétences dans le secteur bancaire, principalement en Uruguay. Il apparaît que la définition des compétences n’est pas une activité neutre, notamment au regard des différences entre femmes et hommes.

Ces quelques exemples montrent la difficulté d'exporter des « bonnes pratiques » qui auraient fait leur preuve sur le continent européen. Ils montrent, comme le rappelle C. Agulhon dans sa postface, la diversité des situations et leur spécificité.

En outre, ces articles font ressortir des clés de lecture que l'on gagnerait à inclure dans nos analyses, notamment : l'importance du secteur informel, le poids des changements politiques et des chocs économiques, le rôle des organisations internationales.

Hors dossier, un article de Florence Jany-Catrice, Emmanuelle Puissant et Thierry Ribault souligne également la diversité des situations professionnelles, ici dans le secteur de l'aide à domicile. La professionnalisation ne se décrète pas selon un modèle unique, elle devra être fondée sur la prise en compte de différentes logiques (analysées ici en termes de convention) dans l'exercice de la profession.

Bonne lecture à tous.

Jean-Frédéric Vergnies, rédacteur en chef 